\title{
Drought stress strengthens the link between chlorophyll fluorescence parameters and photosynthetic traits
}

\author{
Jie Zhuang Equal first author, 1 , Yonglin Wang ${ }^{\text {Equal first author, } 1}$, Yonggang Chi ${ }^{\text {Corresp., 1, } 2}$, Lei Zhou ${ }^{\text {Corresp., 1, } 3}$, Jijing Chen ${ }^{1}$, Wen Zhou ${ }^{1}$, \\ Jun Song ${ }^{1}$, Ning Zhao ${ }^{1}$, Jianxi Ding ${ }^{1}$ \\ ${ }^{1}$ College of Geography and Environmental Sciences, Zhejiang Normal University, Jinhua, Zhejiang, China \\ 2 State Key Laboratory of Resources and Environmental Information System, Institute of Geographic Sciences and Natural Resources Research, Chinese \\ Academy of Sciences, Beijing, China \\ 3 Key Laboratory of Ecosystem Network Observation and Modeling, Institute of Geographic Sciences and Natural Resources Research, Chinese Academy \\ of Sciences, Beijing, China
}

Corresponding Authors: Yonggang Chi, Lei Zhou

Email address: chiyongg@mails.ucas.ac.cn, zhoulei@zjnu.cn

Chlorophyll fluorescence (ChIF) has been used to understand photosynthesis and its response to climate change, particularly with satellite-based data. However, it remains unclear how the ChIF ratio and photosynthesis are linked at the leaf level under drought stress. Here, we examined the link between ChIF ratio and photosynthesis at the leaf level by measuring photosynthetic traits, such as net $\mathrm{CO}_{2}$ assimilation rate $\left(\mathrm{A}_{\mathrm{n}}\right)$, the maximum carboxylation rate of Rubisco $\left(\mathrm{V}_{\mathrm{cmax}}\right)$, the maximum rate of electron transport $\left(\mathrm{J}_{\max }\right)$, stomatal conductance $\left(\mathrm{g}_{\mathrm{s}}\right)$ and total chlorophyll content $\left(\mathrm{ChI}_{\mathrm{t}}\right)$. The ChIF ratio of the leaf level such as maximum quantum efficiency of PSII $\left(F_{v} / F_{m}\right)$ based on fluorescence kinetics. ChIF intensity ratio $\left(\mathrm{LD}_{685} / \mathrm{LD}_{740}\right)$ based on spectrum analysis was obtained. We found that a combination of the stomatal limitation, non-stomatal limitation, and $\mathrm{Ch}_{\mathrm{t}}$ regulated leaf photosynthesis under drought stress, while $J_{\max }$ and $\mathrm{ChI}_{\mathrm{t}}$ governed the ChIF ratio. A significant link between the ChIF ratio and $A_{n}$ was found under drought stress while no significant correlation in the control, which indicated that drought stress strengthens the link between the ChIF ratio and photosynthetic traits. These results suggest that the ChIF ratio can be a powerful tool to track photosynthetic traits of terrestrial ecosystems under drought stress. 
1 Drought stress strengthens the link between chlorophyll fluorescence parameters and

2 photosynthetic traits

3

4

Jie Zhuang Equal first author, 1 , Yonglin Wang Equal first author, 1, Yonggang Chi ${ }^{1,2}$, Lei Zhou ${ }^{1,3}$, Jijing Chen $^{1}$, Wen Zhou ${ }^{1}$, Jun Song ${ }^{1}$, Ning Zhao ${ }^{1}$, Jianxi Ding ${ }^{1}$

${ }^{1}$ College of Geography and Environmental Sciences, Zhejiang Normal University, Jinhua, China ${ }^{2}$ State Key Laboratory of Resources and Environmental Information System, Institute of Geographic Sciences and Natural Resources Research, Chinese Academy of Sciences, Beijing, China

${ }^{3}$ Key Laboratory of Ecosystem Network Observation and Modeling, Institute of Geographic Sciences and Natural Resources Research, Chinese Academy of Sciences, Beijing, China

Corresponding Author:

Yonggang $\mathrm{Chi}^{1}$, Lei Zhou ${ }^{1}$

${ }^{1}$ Zhejiang Normal University 688 Yingbin Road, Jinhua, Zhejiang, 321004, China Email address: chiyongg@mails.ucas.ac.cn (Y.C.); zhoulei@zjnu.cn (L.Z.)

\section{Abstract}

Chlorophyll fluorescence (ChlF) has been used to understand photosynthesis and its response to climate change, particularly with satellite-based data. However, it remains unclear how the ChlF ratio and photosynthesis are linked at the leaf level under drought stress. Here, we examined the link between ChlF ratio and photosynthesis at the leaf level by measuring photosynthetic traits, such as net $\mathrm{CO}_{2}$ assimilation rate $\left(\mathrm{A}_{\mathrm{n}}\right)$, the maximum carboxylation rate of Rubisco $\left(\mathrm{V}_{\mathrm{cmax}}\right)$, the maximum rate of electron transport $\left(\mathrm{J}_{\max }\right)$, stomatal conductance $\left(\mathrm{g}_{\mathrm{s}}\right)$ and total chlorophyll content $\left(\mathrm{Ch}_{\mathrm{t}}\right)$. The $\mathrm{ChlF}$ ratio of the leaf level such as maximum quantum efficiency of PSII $\left(\mathrm{F}_{\mathrm{v}} / \mathrm{F}_{\mathrm{m}}\right)$ based on fluorescence kinetics. ChlF intensity ratio $\left(\mathrm{LD}_{685} / \mathrm{LD}_{740}\right)$ based on spectrum analysis was obtained. We found that a combination of the stomatal limitation, non-stomatal limitation, and $\mathrm{Chl}_{\mathrm{t}}$ regulated leaf photosynthesis under drought stress, while $\mathrm{J}_{\max }$ and $\mathrm{Chl}_{\mathrm{t}}$ governed the ChlF ratio. A significant link between the ChlF ratio and $\mathrm{A}_{n}$ was found under drought stress while no significant correlation in the control, which indicated that drought stress strengthens the link between the $\mathrm{ChlF}$ ratio and photosynthetic traits. These results suggest that the ChlF ratio can be a powerful tool to track photosynthetic traits of terrestrial ecosystems under drought stress. 


\section{Introduction}

The duration and frequency of drought are expected to increase due to global warming (Pachauri et al. 2014). Drought stress increases the frequency of forest fires and the death rate of trees (Anderegg et al. 2013; Phillips et al. 2009), limits leaf photosynthesis and plant productivity (Akhkha et al. 2011; Tezara et al. 2003) and decreases the gross primary production (GPP) (Lee et al. 2013; Li et al. 2019). The terrestrial ecosystem GPP driven by leaf photosynthesis is tightly related to chlorophyll fluorescence (ChlF) (Murchie \& Lawson 2013). In the light reaction of leaf photosynthesis, one of the main de-excitation processes for light absorption of the lightharvesting pigments is the emission of ChlF (Aasen et al. 2019). At the regional scale, solarinduced chlorophyll fluorescence (SIF) is observed based on solar irradiance and vegetation irradiance (Smith et al. 2018). ChlF opens a new perspective as a functional proxy of the terrestrial ecosystem GPP (He et al. 2019). However, it remains uncertain whether the link between $\mathrm{ChlF}$ and photosynthetic traits will be constrained by drought stress. The net $\mathrm{CO}_{2}$ assimilation rate $\left(\mathrm{A}_{\mathrm{n}}\right)$ of leaves decreases during drought stress due to stomatal limitation and non-stomatal limitation (Ashraf \& Harris 2013; Chaves et al. 2002; Flexas \& Medrano 2002). On the one hand, stomatal limitation means that drought stress affects the diffusion process of $\mathrm{CO}_{2}$ from the stomata to the intercellular spaces then reduces $\mathrm{A}_{\mathrm{n}}$ (Flexas et al. 2014; Lawlor \& Tezara 2009). A study of pine seedlings found that the limitation of stomatal conductance $\left(g_{s}\right)$ to $A_{n}$ increased during drought stress (Anev et al. 2016). On the other hand, non-stomata limitations include biochemical limitation and mesophyll conductance $\left(\mathrm{g}_{\mathrm{m}}\right)$ limitation (Salmon et al. 2020). Drought stress decreases the maximum carboxylation rate of Rubisco $\left(\mathrm{V}_{\text {cmax }}\right)$ and the maximum rate of electron transport $\left(\mathrm{J}_{\max }\right)$ then reduces $\mathrm{A}_{\mathrm{n}}$ (Flexas et al. 2004; Niinemets \& Keenan 2014; Rho et al. 2012). A study of Eucalyptus and Quercus found that the $\mathrm{V}_{\mathrm{cmax}}$ and $\mathrm{J}_{\max }$ in the drought were significantly lower than those in the control (Zhou et al. 2014). Also, drought stress leads to a reduction of $\mathrm{g}_{\mathrm{m}}$, which limits the diffusion of $\mathrm{CO}_{2}$ from the leaf intercellular spaces to the sites of the dark reactions of photosynthesis in chloroplasts (Flexas et al. 2012; Rancourt et al. 2015). Recent studies have incorporated the effects of stomatal and non-stomatal limitations for predicting the response of photosynthesis to drought stress (Drake et al. 2017; Salmon et al. 2020). Thus, understanding the relative contributions of stomatal limitation versus non-stomatal limitation to the decline of $\mathrm{A}_{\mathrm{n}}$ is fundamental to project the effect of drought stress (Campos et al. 2014a; Chen et al. 2015; Gimeno et al. 2019). ChlF is a fast, accurate, and non-destructive probe, which can be utilized to obtain information about the metabolism of photosystem II (PSII) (Baker 2008). Photosynthetically active radiation is absorbed by chlorophyll and accessory pigments of chlorophyll-protein complexes and migrated to the reaction centers of photosystems I (PSI) and II (PSII), where the conversion of the quantum photosynthetic process takes place, and is then consumed by photochemistry, heat dissipation, or re-emitted as ChlF (Porcar-Castell et al. 2014). Due to the competition between these three processes, ChlF can be used to obtain photosynthesis information (Maxwell \& Johnson 2000; Murchie \& Lawson 2013). In recent years, researchers have used the changes of 
80 ChlF to explore photosynthetic apparatus under different environmental situations (Badr \& 81 Brueggemann 2020; Hajihashemi et al. 2020; Iqbal et al. 2019; Xu et al. 2020).

82 Most studies on ChlF are based on polyphasic fluorescence transient (OJIP) to obtain

83 fluorescence kinetic parameters, such as the maximum quantum efficiency of PSII reaction

84 centers $\left(\mathrm{F}_{\mathrm{v}} / \mathrm{F}_{\mathrm{m}}\right)$, the photochemical $(\mathrm{qP})$ and non-photochemical (NPQ) quenching (Mathobo et

85 al. 2017). By analyzing the fluorescence kinetic curves, we can obtain abundant information

86 about the structure and the function of PSII during stress conditions (Krause \& Weis 1991;

87 Stirbet et al. 2018). $F_{v} / F_{m}$ is the maximal quantum efficiency of PSII reaction centers which

88 positively correlated with the activity of primary PSII photochemistry (Butler 1978; Stirbet et al.

89 2018). Low $F_{v} / F_{m}$ represents that light energy absorbed by PSII reaction centers may be

90

91

92

93

94

95

96

97

98

99

100

101

102

103

104

105

106

107

108

109

110

111

112

113

114

115

116

117

118 underutilized (Fracheboud \& Leipner 2003). PSII is considered to be a susceptible component of the photosynthetic machinery and will often bear the brunt of stress conditions, which leads to a decrease in $F_{v} / F_{m}$ (Demmig-Adams \& Adams 2018; Long 1994). For example, a study of Viburnum found that the $\mathrm{F}_{\mathrm{v}} / \mathrm{F}_{\mathrm{m}}$ significantly decreased during a severe drought (Tribulato et al. 2019). Likewise, Li et al. (2008) analyzed the effect of drought stress on the photochemical efficiency of leaves and found that the $F_{v} / F_{m}$ was decreased while the NPQ increased during severe drought stress. The decrease in $\mathrm{F}_{\mathrm{v}} / \mathrm{F}_{\mathrm{m}}$ indicates the down-regulation of photosynthesis or photoinhibition under stress (Lichtenthaler \& Rinderle 1988; Van Kooten 1990). Therefore, fluorescence kinetic parameters have been used to determine photosynthetic traits successfully. Laser-induced fluorescence spectrum analysis is a specific technique that provides a new approach to monitor vegetation physiology remotely (Gouveia-Neto et al. 2011; Utkin et al. 2014). Leaves have two fluorescence emission peaks located in the $685 \mathrm{~nm}$ of the red region $\left(\mathrm{LD}_{685}\right)$ and the $740 \mathrm{~nm}$ of the far-red region $\left(\mathrm{LD}_{740}\right)$ (Buschmann 2007), which are closely related to the chlorophyll content $\left(\mathrm{Chl}_{\mathrm{t}}\right)$ (Kalmatskaya et al. 2016; Nyachiro et al. 2001). $\mathrm{LD}_{685}$ and $\mathrm{LD}_{740}$ both increase with the increases of $\mathrm{Chl}_{\mathrm{t}}$ at low $\mathrm{Chl}_{\mathrm{t}}$, while in the case of higher $\mathrm{Chl}_{\mathrm{t}}$, $\mathrm{LD}_{685}$ will decrease due to re-absorption of the emitted red band fluorescence by the chlorophyll absorption bands (Baker 2008; Buschmann 2007). It has been demonstrated that $\mathrm{LD}_{685} / \mathrm{LD}_{740}$ is a good inverse indicator of the $\mathrm{Chl}_{\mathrm{t}}$ and reflects the active degree of photosynthesis (Baker 2008; D'Ambrosio et al. 1992). However, there has been a lack of synchronous observation for fluorescence kinetic parameters and fluorescence spectrum, which can be used to evaluate the response of leaf to drought stress (Magney et al. 2017).

In this study, cucumber was used as an ideal test plant due to its short growth period, easy survival, and widely used in ecophysiology research ( $\mathrm{Li}$ et al. 2008). A drought experiment was conducted over an 8-day from November 24 to December 1, 2018. Gas exchange parameters, fluorescence kinetic parameters, fluorescence spectrum, and chlorophyll content were measured in cumber leaf. Here, our overall objective was to assess the response of photosynthesis traits and ChlF ratio to drought stress based on synchronous observation of gas exchange and fluorescence under drought stress. We hypothesize that (i) photosynthesis will be inhibited by stomatal and non-stomatal limitations under drought stress, (ii) the relationship between $\mathrm{ChlF}$ ratio and 
119 chlorophyll content may be changed under drought stress, and (iii) ChlF ratio can be used to

120 reflect photosynthesis.

121

122

\section{Materials \& Methods}

123

Plant material and experimental design

124

Cucumbers (Cucumis sativus L.) were used as plant material, which was cultured in plastic

125 seedling pots $(12 \times 8 \times 10 \mathrm{~cm})$ and cultivated in a growth chamber. Growth chamber temperature was $20-25^{\circ} \mathrm{C}$ at day and $15-18{ }^{\circ} \mathrm{C}$ at night then light intensity was $1200 \mu \mathrm{mol} \mathrm{m}^{-2} \mathrm{~s}^{-1}$ with relative humidity $(\mathrm{RH})$ at $75 \%$. The potting soil was a composite culture substrate composed of wood chips, peat, pine bark, and sand. Six mature cucumbers were divided randomly into two treatments: drought and control, with three replicates per treatment. The drought treatment started on November 21,2018 . The soil moisture content $\left(\theta_{\mathrm{g}}\right)$ of the drought was measured about $8 \pm 2 \%$ by the weighing method on November 23,2018 , while the soil moisture content of the control was about $15 \pm 1 \%$. During the experiment, the plants of the drought treatment were not irrigated, while the plants of the control group were irrigated daily. The upmost, sunlit, dark green, fully unfolded and mainstem leaves were used to measure gas exchange and $\mathrm{F}_{\mathrm{v}} / \mathrm{F}_{\mathrm{m}}$, and adjacent leaves were used to measure laser-induced chlorophyll fluorescence and $\mathrm{Chl}_{\mathrm{t}}$. Measurement of the $\mathrm{CO}_{2}$ response curve and chlorophyll fluorescence Typical $\mathrm{A}_{\mathrm{n}} / \mathrm{C}_{\mathrm{i}}$ curves (light-saturated net $\mathrm{CO}_{2}$ assimilation rate versus intercellular $\mathrm{CO}_{2}$ concentrations) were measured using the Li-6800 portable photosynthesis system (LI-COR Inc., USA) from 8:00 to 11:30 after two days of drought treatment. The upmost fully unfolded, mainstem leaves were measured at leaf temperature of $25^{\circ} \mathrm{C}, \mathrm{RH}$ of $50-60 \%$, and photosynthetic photon flux density (PPFD) of $1500 \mu \mathrm{mol} \mathrm{m}^{-2} \mathrm{~s}^{-1}$. The carbon dioxide concentration of the reference chamber was set as 400, 100, 50, 100, 400, 600, 800, $1000 \mu \mathrm{mol} \mathrm{mol}^{-1}$. A total of 54 $\mathrm{A}_{\mathrm{n}} / \mathrm{C}_{\mathrm{i}}$ curves were taken (i.e., 3 samples per treatment $\times 7$ times per sample $\times 2$ treatments +6 samples per treatment on the first day $\times 2$ treatments $=54$ curves ). Before measuring the $A_{n} / C_{i}$ curve, the leaves were adapted for 5 minutes at a $\mathrm{CO}_{2}$ concentration of $400 \mu \mathrm{mol} \mathrm{mol}{ }^{-1}$. Measurements of the $A_{n} / C_{i}$ curve were taken when gas exchange had equilibrated (taken to be when the coefficient of variation for the $\mathrm{CO}_{2}$ partial pressure differential was below $1 \%$ between the sample and reference analyzers). This condition was typically achieved within 1-2 min after a stable $\mathrm{CO}_{2}$ concentration had been reached.

150 $\mathrm{F}_{\mathrm{v}} / \mathrm{F}_{\mathrm{m}}$ was measured using the Li-6800 fluorescence leaf chamber (LI-COR Inc., USA) connected to an LI-6800 portable photosynthesis system after dark treatment for one night. In the evening before the measurement, the upmost fully unfolded, mainstem leaves used to measure the dark-adapted fluorescence parameters were wrapped with tin foil. The rectangular flash was configured with a red target of $8000 \mu \mathrm{mol} \mathrm{m}^{-2} \mathrm{~s}^{-1}$, a duration of $1000 \mathrm{~ms}$, the output rate of 100 $\mathrm{Hz}$, and a margin of 5 points. peak emission of $456 \mathrm{~nm}$ (Dslaser, China), USB4000 grating spectrometer, VIS-NIR band optical fiber (Ocean Optics, USA), Long-pass optical filter (AT6001p, Chroma Technology Corp, 
159 USA), and computer with software (Figure 1). The light source output power is $40 \mathrm{~mW}$, and the

160

161

162

163

164

165

166

167

168

169

170

171

172

173

174

175

176

177

178

179

180

181

182

183

184 corresponding light source input voltage is $5.7 \mathrm{~V}$. The spectrometer used in the experiment has a resolution of $1.5 \mathrm{~nm}$, an integral time of $3.8 \mathrm{~ms}-10 \mathrm{~s}$, and detector covers of 200-1100 nm. The spectrometer is equipped with a USB port on the side, which is connected to the computer and directly powered by the computer. The linear array CCD detector (Toshiba, Japan) of the USB4000 spectrometer has a pixel count of 3648 (Li et al. 2009). SMA905 fiber adapter (DingSuo Technologies, China) is used as a connector to match the VIS-NIR band optical fiber and USB4000 spectrometer. VIS-NIR band optical fiber has an optical fiber core diameter of $1000 \mathrm{um}$, numerical aperture of 0.22 , and divergent Angle of $25.4^{\circ}$. The included angle between light source and leaves is $45^{\circ}$, the fiber is perpendicular to the leaves with a distance of $4.5 \mathrm{~cm}$. The long-pass optical filter with a transmission wavelength range greater than $600 \mathrm{~nm}$, and transmittance greater than $90 \%$ to prevent the influence of reflected light on the fluorescence spectrum. The chlorophyll fluorescence of $650-850 \mathrm{~nm}$ was received by optical fiber then collected by the spectrometer. SpectraWiz software (StellarNet Inc., Tampa FL, USA) was used to set up to collect three spectra and take the average, the integrating time with $600 \mathrm{~ms}$.

\section{Measurement of chlorophyll content}

The leaves used to measure the ChlF spectrum were cut out and used to measure $\mathrm{Chl}_{\mathrm{t}}$. Starting from November 24, 2018, Chl $\mathrm{t}_{\mathrm{t}}$ was measured every other day. The control and drought were repeated three times (repeated six times on the first day), for a total of four measurements. A total of 30 chlorophyll content were collected (i.e., 3 samples per treatment $\times 3$ times per sample $\times 2$ treatments +6 samples per treatment on the first day $\times 2$ treatments $=30$ ). Acetone and anhydrous ethanol were mixed into the extract at a volume of $1: 1$. The leaves were cut into filaments and weighed at $0.1 \mathrm{~g}$ in the test tube containing the mixture, which was placed in the dark place. After the material was completely white, the optical density at $663 \mathrm{~nm}$ and $645 \mathrm{~nm}$ was measured by spectrophotometer (MAPADA, China). The $\mathrm{Chl}_{\mathrm{t}}$ in this study was expressed as follows:

$$
\begin{gathered}
\mathrm{Chl}_{\mathrm{a}}=12.72 \times \mathrm{A}_{663}-2.59 \times \mathrm{A}_{645} \times 0.1 \\
\mathrm{Chl}_{\mathrm{b}}=22.88 \times \mathrm{A}_{663}-4.67 \times \mathrm{A}_{645} \times 0.1 \\
\mathrm{Chl}_{\mathrm{t}}=\mathrm{Chl}_{\mathrm{a}}+\mathrm{Chl}_{\mathrm{b}}
\end{gathered}
$$

185

186

187

188

189

190

191

192

193

194

195

Where $\mathrm{Chl}_{\mathrm{a}}$ is the chlorophyll $\mathrm{A}$ content $\left(\mathrm{mg} \mathrm{g}^{-1}\right)$, and $\mathrm{Chl}_{\mathrm{b}}$ is the chlorophyll $\mathrm{B}$ content $\left(\mathrm{mg} \mathrm{g}^{-1}\right)$, and $\mathrm{Chl}_{\mathrm{t}}$ is the total chlorophyll content $\left(\mathrm{mg} \mathrm{g}^{-1}\right)$. The $\mathrm{A}_{645}$ and $\mathrm{A}_{663}$ are absorbances at wavelengths 645 and 663, respectively.

\section{Statistical Analysis}

$\mathrm{V}_{\mathrm{cmax}}$ and $\mathrm{J}_{\max }$ were estimated by fitting the $\mathrm{A}_{\mathrm{n}} / \mathrm{C}_{\mathrm{i}}$ curves using a spreadsheet-based software developed by Sharkey (Sharkey 2016). The chlorophyll fluorescence collection program for the spectrometer was written based on the underlying program of the spectrometer with MATLAB software (Yu Haiye 2009). Dark current noise is removed from the chlorophyll fluorescence spectrum curve and the curve is smoothed by Savitzky-Golay filtering (Gorry 1990). We repeated measurements of the same six individuals. Repeated Measures ANOVA (RMANOVA) was used to test the effects of drought stress on photosynthetic traits and 
196

197

198

199

200

201

202

203

204

205

206

207

208

209

210

211

212

213

214

215

216

217

218

219

220

221

222

223

224

225

226

227

228

229

230

231

232

233

234

235

chlorophyll fluorescence parameters. The effects were considered to be significantly different if $\mathrm{P}<0.05$. Besides, a mixed-effect linear model was used to evaluate the effect of $\mathrm{V}_{\mathrm{cmax}}, \mathrm{J}_{\max }, \mathrm{g}_{\mathrm{s}}$, and $\mathrm{Chl}_{\mathrm{t}}$ on $\mathrm{A}_{\mathrm{n}}$ and chlorophyll fluorescence parameters. The individual plant was used as a random term. Similar method was used to test the relation between $A_{n}$ and chlorophyll fluorescence parameters. All statistical analyses were performed using SPSS 25.0 (SPSS Inc., USA).

\section{Results}

\section{The response of leaf photosynthetic traits and $\mathrm{ChIF}$ ratio to drought}

The drought stress caused a significant reduction in $A_{n}, V_{c \max }, J_{\max }, g_{s}$, and $C_{1} l_{t}$ compared with control $(\mathrm{P}<0.05)$. The averages of $\mathrm{A}_{\mathrm{n}}$ were $1.0 \pm 0.1 \mu \mathrm{mol} \mathrm{m} \mathrm{m}^{-2} \mathrm{~s}^{-1}$ and $2.0 \pm 0.2 \mu \mathrm{mol} \mathrm{m}^{-2} \mathrm{~s}^{-1}$ in drought and control (Figure 2a). The averages of $\mathrm{V}_{\mathrm{cmax}}$ and $\mathrm{J}_{\max }$ were $92.0 \pm 5.0 \mu \mathrm{mol} \mathrm{m}^{-2} \mathrm{~s}^{-1}$ and $117.0 \pm 5.0 \mu \mathrm{mol} \mathrm{m}^{-2} \mathrm{~s}^{-1}$ in drought, respectively (Figure 3a, c). For control, the averages of $\mathrm{V}_{\mathrm{cmax}}$ and $\mathrm{J}_{\max }$ were $105.9 \pm 4.3 \mu \mathrm{mol} \mathrm{m}^{-2} \mathrm{~s}^{-1}$ and $141.0 \pm 5.2 \mu \mathrm{mol} \mathrm{m}^{-2} \mathrm{~s}^{-1}$, respectively (Figure 3a, c). Compared to control, the averages of $\mathrm{V}_{c \max }$ and $\mathrm{J}_{\max }$ decreased $13.1 \%$ and $17.1 \%$, while the $\mathrm{g}_{\mathrm{s}}$ and $\mathrm{Chl}_{\mathrm{t}}$ in drought $\left(0.1 \pm 0.01 \mathrm{~mol} \mathrm{~m}^{-2} \mathrm{~s}^{-1}\right.$ and $\left.1.6 \pm 0.1 \mathrm{mg} \mathrm{g}^{-1}\right)$ were reduced by $27.1 \%$ and $21.5 \%$ compared with control $\left(0.1 \pm 0.01 \mathrm{~mol} \mathrm{~m}^{-2} \mathrm{~s}^{-1}\right.$ and $\left.2.1 \pm 0.1 \mathrm{mg} \mathrm{g}^{-1}\right)$ (Figure $3 \mathrm{e}, \mathrm{g}$ ). Compared to the control plants, the averages of $F_{v} / F_{m}$ decreased 6.8\% (0.74 \pm 0.01 to $0.69 \pm$ $0.13)$, while $\mathrm{LD}_{685} / \mathrm{LD}_{740}$ increased $10.7 \%(1.1 \pm 0.4$ to $1.2 \pm 0.3)$.

\section{Control factors for $A_{n}$ and $\mathrm{ChIF}$ ratio}

Significant positive correlation was found between $A_{n}$ and $V_{\text {cmax }}$ in the control $\left(R^{2}=0.15, P=\right.$ $0.03)$ and drought stress $\left(\mathrm{R}^{2}=0.45, \mathrm{P}<0.001\right)$. There was a significant positive correlation between $\mathrm{J}_{\max }$ and $\mathrm{A}_{\mathrm{n}}$ in the control $\left(\mathrm{R}^{2}=0.12, \mathrm{P}=0.04\right)$ and under drought stress $\left(\mathrm{R}^{2}=0.60, \mathrm{P}<\right.$ $0.001)$. Besides the significant positive correlation $\left(R^{2}=0.11, P=0.05\right)$ between $g_{s}$ and $A_{n}$ in the control, a significant positive correlation $\left(\mathrm{R}^{2}=0.48, \mathrm{P}<0.001\right)$ in the drought stress was observed. A poor correlation $\left(\mathrm{R}^{2}=0.07, \mathrm{P}=0.84\right)$ between $\mathrm{A}_{\mathrm{n}}$ and $\mathrm{Ch}_{\mathrm{t}}$ was observed in the control, whereas the correlation was positive $\left(\mathrm{R}^{2}=0.56, \mathrm{P}<0.001\right)$ in the drought stress (Figures 4a-d).

A significant positive correlation between $\mathrm{F}_{\mathrm{v}} / \mathrm{F}_{\mathrm{m}}$ and $\mathrm{V}_{\mathrm{cmax}}$ was found in the drought $\left(\mathrm{R}^{2}=0.13, \mathrm{P}\right.$ $=0.03$ ). Meanwhile, a marginally positive correlation between $F_{v} / F_{m}$ and $J_{\max }$ was observed in the control $\left(\mathrm{R}^{2}=0.09, \mathrm{P}=0.09\right)$, and a significant positive correlation was observed in the drought stress $\left(\mathrm{R}^{2}=0.28, \mathrm{P}=0.03\right)$. In addition, a significant positive correlation has been found between $F_{v} / F_{m}$ and $g_{s}$ in the control $\left(R^{2}=0.28, P=0.003\right)$ while the correlation was poor under drought stress $\left(R^{2}=0.01, P=0.22\right)$. No significant correlation $\left(R^{2}=0.03, P=0.27\right)$ was observed between $\mathrm{F}_{\mathrm{v}} / \mathrm{F}_{\mathrm{m}}$ and $\mathrm{Ch}_{\mathrm{t}}$ in the control group, whereas a significant positive correlation was found between $\mathrm{F}_{\mathrm{v}} / \mathrm{F}_{\mathrm{m}}$ and $\mathrm{Chl}_{\mathrm{t}}$ under drought stress $\left(\mathrm{R}^{2}=0.29, \mathrm{P}=0.02\right)$ (Figures 4e-h). A significant negative correlation was found between $\mathrm{LD}_{685} / \mathrm{LD}_{740}$ and $\mathrm{V}_{\text {cmax }}$ in drought stress $\left(\mathrm{R}^{2}=0.18, \mathrm{P}=0.009\right)$, while there was no significant correlation between $\mathrm{LD}_{685} / \mathrm{LD}_{740}$ and $\mathrm{V}_{\text {cmax }}$ in control $\left(\mathrm{R}^{2}=0.03, \mathrm{P}=0.50\right)$. There was no significant correlation between $\mathrm{LD}_{685} / \mathrm{LD}_{740}$ and $\mathrm{J}_{\max }$ in control $\left(\mathrm{R}^{2}=0.03, \mathrm{P}=0.69\right)$, while a significant negative correlation was observed 
236 between $\mathrm{LD}_{685} / \mathrm{LD}_{740}$ and $\mathrm{J}_{\max }$ in drought stress $\left(\mathrm{R}^{2}=0.13, \mathrm{P}=0.04\right)$. No significant correlation 237 was observed between $\mathrm{LD}_{685} / \mathrm{LD}_{740}$ and $\mathrm{g}_{\mathrm{s}}$ in control $(\mathrm{P}=0.13)$ and drought stress $(\mathrm{P}=0.09)$.

238 There was no significant correlation between the $\mathrm{LD}_{685} / \mathrm{LD}_{740}$ and $C h l_{\mathrm{t}}$ in the control $\left(\mathrm{R}^{2}=0.06\right.$, $239 \mathrm{P}=0.68$ ), while a significant negative correlation between $\mathrm{LD}_{685} / \mathrm{LD}_{740}$ and $\mathrm{Chl}_{\mathrm{t}}$ in drought 240 stress $\left(\mathrm{R}^{2}=0.25, \mathrm{P}=0.03\right)$ (Figures $\left.4 \mathrm{i}-1\right)$.

241 Correlation between $A_{n}$ and $C h I F$ ratio

242 There was a marginally positive correlation between $A_{n}$ and $F_{v} / F_{m}$ in the control $\left(R^{2}=0.08, P=\right.$

243 0.09). However, the correlation between $A_{n}$ and $F_{v} / F_{m}$ was significant positive in drought stress

$244 \quad\left(R^{2}=0.28, P=0.003\right)$. Similarly, there was no significant correlation between $A_{n}$ and

$245 \mathrm{LD}_{685} / \mathrm{LD}_{740}$ in the control $\left(\mathrm{R}^{2}=0.02, \mathrm{P}=0.45\right)$, while a significant negative correlation was

246

247

248

249

250

251

252

253

254

255

256

257

258

259

260

261

262

263

264

265 found between $A_{n}$ and $L_{68} / L_{740}$ in drought stress $\left(R^{2}=0.17, P=0.02\right)$ (Figures $\left.5 a-b\right)$.

\section{Discussion}

\section{Combination of the stomatal limitation, non-stomatal limitations, and chlorophyll content regulated leaf photosynthesis under drought stress}

As expected, drought stress significantly decreased the leaf photosynthesis of cucumber (Figure 2a). Although drought stress is known to reduce leaf photosynthesis, the processes responsible for the key limitations are still a matter of debate (Chaves et al. 2002; Flexas \& Medrano 2002; Pinheiro \& Chaves 2011). Here, our study found that the combination of the stomatal limitation, non-stomatal limitations, and chlorophyll content regulated the decrease of leaf photosynthesis under drought stress (Figures 4a, b, c, d). Increasing evidence shows that leaf photosynthesis under drought stress is not limited by a single process (Zhou et al. 2015). It has been demonstrated that stomatal closure reduces photosynthesis and transpiration while improving water use efficiency due to acclimation under drought stress (Feller 2016; Lamaoui et al. 2018). Non-stomatal limitations were defined as the sum of the contributions of mesophyll conductance and leaf biochemistry, which directly reflect the biochemical process of photosynthesis (Grassi \& Magnani 2005). The decrease in $V_{c \max }$ and $J_{\max }$ may result from a decrease in the amount of active Rubisco and an inadequate supply of ATP or NADPH or to a low enzymatic activity during the photosynthetic carbon reduction cycle (Campos et al. 2014b; Flexas et al. 2004; PeñaRojas et al. 2004). Recent studies found that stomatal and non-stomatal limitations to

266

267

268

269

270

271

272

273

274

275 photosynthesis are coordinated on similar timescales, and suggested that non-stomatal limitations should be included in predict the model of photosynthesis response to drought (Drake et al. 2017; Salmon et al. 2020). A study of three Mediterranean species has found that the decrease of $A_{n}$ was simultaneous regulated by stomatal and biochemical limitations during drought stress (Varone et al. 2012). In addition, $\mathrm{Ch}_{\mathrm{t}}$ is the main pigment that absorbs photosynthetically active radiation and can indirectly reflect the integrity of the photosynthetic device (Streit et al. 2005). $\mathrm{Chl}_{\mathrm{t}}$ can be used as a functional trait to evaluate drought stress (Pilon et al. 2018; Pilon et al. 2014). Therefore, our observations suggest that the combination of the stomatal limitation, nonstomatal limitation, and chlorophyll content should be taken into consideration in process-based models for simulating photosynthesis in terrestrial ecosystems under drought stress. 


\section{$276 \mathbf{J}_{\max }$ and $\mathbf{C h}_{\mathbf{t}}$ governed $\mathbf{C h l F}$ ratio under drought stress}

277 Leaf $\mathrm{F}_{\mathrm{v}} / \mathrm{F}_{\mathrm{m}}$ is a crucial chlorophyll fluorescence parameter for evaluating the health or integrity

278 of the internal apparatus under drought stress (Krause \& Weis 1991; Urban et al. 2017). Here, we

279 found that $\mathrm{F}_{\mathrm{v}} / \mathrm{F}_{\mathrm{m}}$ was significantly decreased under drought stress (Figure 2b), which revealed

280 that the PSII may be damaged under drought stress, and the primary reaction of photosynthesis

281 may be inhibited (Lichtenthaler \& Rinderle 1988). The fluorescence parameters of the leaves are

282 changed in two ways under stress conditions. The minimal fluorescence $\left(\mathrm{F}_{\mathrm{o}}\right)$ increases due to

283 obstruction of the electron flow through PSII, and plastoquinone acceptor (QA-) cannot be

284 completely oxidized during stress. Simultaneously, the reduction of $F_{m}$ during stress may be

285 affected by decreased activity of the water-splitting enzyme complex and perhaps a concomitant

286 cyclic electron transport within or around PSII (Porcar-Castell et al. 2014). Therefore, $F_{v} / F_{m}$

287 will decrease under drought stress. Our finding was consistent with a previous studying, in which

288 drought stress inhibited the photochemical activity of PSII and decreased leaf $F_{v} / F_{m}$ (Meng et al.

289 2016). Meanwhile, our study showed that $\mathrm{F}_{\mathrm{v}} / \mathrm{F}_{\mathrm{m}}$ was largely related to $\mathrm{J}_{\max }$ and $\mathrm{Ch}_{\mathrm{t}}$ under

290 drought stress (Figures $4 \mathrm{f}, \mathrm{h}$ ). It has been proposed that $\mathrm{J}_{\max }$ is decreased by drought stress,

291 which prevents the electron from rapidly transferring back, and hinders the whole photochemical

292 process (Baker \& Rosenqvist 2004; Khatri \& Rathore 2019). Similarly, the decrease in $\mathrm{Chl}_{\mathrm{t}}$ will

293 weaken the photochemical process, which demonstrates the dependence of the light absorption

294 and fluorescence emission on the concentration of chlorophyll molecules in the chloroplast

295 (Nyachiro et al. 2001). Thus, the significant linear relationship between $F_{v} / F_{m}$ and $J_{\max }$ and $\mathrm{Ch}_{t}$

296 observed in drought stress jointly indicates the importance of $\mathrm{J}_{\max }$ and $\mathrm{Ch}_{\mathrm{t}}$ in governing

297 chlorophyll fluorescence.

298 In our study, the $\mathrm{LD}_{685} / \mathrm{LD}_{740}$ based on spectral analysis was significantly increased under 299 drought stress (Figure 2c). This finding was similar to the study of Meng et al. (2016), in which 300 the fluorescence intensity ratio increased when the PSII was damaged. Moreover, $\mathrm{LD}_{685} / \mathrm{LD}_{740}$ 301 was largely regulated by $\mathrm{J}_{\max }$ and $\mathrm{Ch}_{\mathrm{t}}$ under drought stress (Figure $4 \mathrm{j}, 1$ ). The previous study

302 found that changes in the chlorophyll content resulted in changes of more than $90 \%$ for the $303 \quad \mathrm{~F}_{690} / \mathrm{F}_{735}$ ratio (Csintalan et al. 1998). There was a significant negative correlation between the

$304 \mathrm{LD}_{685} / \mathrm{LD}_{740}$ and $\mathrm{Ch}_{\mathrm{t}}$ under drought stress (Figure 41 ). The chlorophyll absorption spectrum 305 overlaps with the chlorophyll fluorescence emission spectrum in the red band, which results in 306 the $\mathrm{LD}_{685}$ being decreased by re-absorption in the case of higher chlorophyll content. The effect 307 of re-absorption on the red band is stronger than that of the far-red band, and therefore the $308 \mathrm{LD}_{685} / \mathrm{LD}_{740}$ will decrease (Buschmann 2007). The $\mathrm{LD}_{685} / \mathrm{LD}_{740}$ represents an ideal tool for 309 evaluating the change of $\mathrm{Ch}_{\mathrm{t}}$ and reflects the photochemical activity of PSII indirectly under 310 drought stress (Figure 4j, 1). Spectral analysis has been used to directly assess ecosystem 311 functioning under climate change. For instance, Gameiro et al. (2016) found a significant linear 312 relationship between the fluorescence intensity ratio and leaf water content of Arabidopsis.

313 Norikane et al. (2003) successfully monitor the growth of tomato under drought stress based on 314 spectral analysis. Here, synchronous observation of $\mathrm{LD}_{685} / \mathrm{LD}_{740}$ and $\mathrm{F}_{\mathrm{v}} / \mathrm{F}_{\mathrm{m}}$ based on spectral 
315 analysis and fluorescence kinetics suggest that $\mathrm{LD}_{685} / \mathrm{LD}_{740}$ can be used as an indicator for 316 detection of plant stress.

317 Drought stress strengthens the relationship between net $\mathrm{CO}_{2}$ assimilation rate $\left(\mathrm{A}_{n}\right)$ and 318 ChlF ratio

319 Our study reported a significant relationship between the $A_{n}$ and ChlF ratio under drought stress,

320

321

322

323

324

325

326

327

328

329

330

331

332

333

334

335

336

337

338

339

340

341

342

343

344

345

346

347

348

349

350

351

352

353

354

while no significant correlation was found in the control (Figure 5a, b). The strengthening relationship between $\mathrm{A}_{\mathrm{n}}$ and $\mathrm{ChlF}$ ratio may be ascribed to variations of $\mathrm{J}_{\max }$ and $\mathrm{Chl}_{\mathrm{t}}$ under drought stress. On the one hand, the reduction of $F_{v} / F_{m}$ and $J_{\max }$ under drought indicated that the photosynthetic electron transport was damaged. Drought stress damages the reaction center of PSII and inhibits the electron transfer process of photosynthesis, which reduces the light energy conversion efficiency of PSII (Brestic et al. 1995; Cornic \& Fresneau 2002; Longenberger et al. 2009). On the other hand, drought stress deforms the leaf chloroplast layer structure and reduces chlorophyll content (Batra et al. 2014). So, $\mathrm{J}_{\max }$ and $\mathrm{Ch}_{\mathrm{t}}$ became limiting factors for the $\mathrm{A}_{\mathrm{n}}$ and $\mathrm{ChlF}$ ratio under drought stress (Figures $4 \mathrm{~b}, \mathrm{~d}, \mathrm{f}, \mathrm{h}, \mathrm{j}, \mathrm{l}$ ). The strengthening relationship between $\mathrm{A}_{\mathrm{n}}$ and ChlF ratio has been observed in previous studies (Murchie \& Lawson 2013; Su et al. 2015). For example, Wang et al. (2018) found a significant linear relationship between $A_{n}$ and $\mathrm{F}_{\mathrm{v}} / \mathrm{F}_{\mathrm{m}}$ in the soybean experiment under drought conditions. Batra et al. (2014) found similar results by studying the $\mathrm{ChlF}$ ratio characteristics of mung beans under drought conditions.

Therefore, ChlF ratio based on spectral analysis and fluorescence kinetics was a better indicator of the photosynthetic capacity under drought stress.

\section{Conclusions}

Our results demonstrate that the decrease in cucumber leaf photosynthesis is regulated by stomatal limitation, non-stomatal limitation, and chlorophyll content under drought stress. We recommend that incorporated the effects of stomatal, non-stomatal limitations and chlorophyll content, and applied it to the prediction of plant photosynthesis response to drought stress. The $\mathrm{J}_{\max }$ and $\mathrm{Chl}_{\mathrm{t}}$ are key limiting factors for the ChlF ratio under drought stress, and the ChlF can characterize plant photosynthetic capacity as new technology under drought stress.

\section{Acknowledgments}

We gratefully acknowledge Yunhui Tan, Meijuan Fu, and Yao Si for their help with the measurement of the photosynthesis and chlorophyll fluorescence. We thank two anonymous reviewers and editor for their constructive comments.

\section{References}

Aasen H, Van Wittenberghe S, Medina NS, Damm A, Goulas Y, Wieneke S, Hueni A, Malenovsky Z, Alonso L, Pacheco-Labrador J, Pilar Cendrero-Mateo M, Tomelleri E, Burkart A, Cogliati S, Rascher U, and Mac Arthur A. 2019. Sun-Induced Chlorophyll Fluorescence II: Review of Passive Measurement Setups, Protocols, and Their Application at the Leaf to Canopy Level. Remote Sensing 11. 10.3390/rs11080927 
355

356

357

358

359

360

361

362

363

364

365

366

367

368

369

370

371

372

373

374

375

376

377

378

379

380

381

382

383

384

385

386

387

388

389

390

391

392

393

394

395

396

397

398

399

400

401

402

403

404

405

Akhkha A, Boutraa T, and Alhejely A. 2011. The Rates of Photosynthesis, Chlorophyll Content, Dark Respiration, Proline and Abscicic Acid (ABA) in Wheat (Triticum durum) under Water Deficit Conditions. International Journal of Agriculture and Biology 13:215-221.

Anderegg WRL, Kane JM, and Anderegg LDL. 2013. Consequences of widespread tree Mortality triggered by drought and temperature stress. Nature Climate Change 3:30-36.

Anev S, Ivanova A, Tzvetkova N, Panayotov M, and Yurukov S. 2016. Stomatal control on photosynthesis in drought-treated subalpine pine saplings. Genetics Plant Physiology 6:43-53.

Ashraf M, and Harris PJC. 2013. Photosynthesis under stressful environments: An overview. Photosynthetica 51:163-190. 10.1007/s11099-013-0021-6

Badr A, and Brueggemann W. 2020. Comparative analysis of drought stress response of maize genotypes using chlorophyll fluorescence measurements and leaf relative water content. Photosynthetica 58:638-645. 10.32615/ps.2020.014

Baker NR. 2008. Chlorophyll fluorescence: A probe of photosynthesis in vivo. Annual Review of Plant Biology 59:89-113. 10.1146/annurev.arplant.59.032607.092759

Baker NR, and Rosenqvist E. 2004. Applications of chlorophyll fluorescence can improve crop production strategies: an examination of future possibilities. Journal of Experimental Botany 55:1607-1621. 10.1093/jxb/erh196

Batra NG, Sharma V, and Kumari N. 2014. Drought-induced changes in chlorophyll fluorescence, photosynthetic pigments, and thylakoid membrane proteins of Vigna radiata. Journal of Plant Interactions 9:712-721. 10.1080/17429145.2014.905801

Brestic M, Cornic G, Freyer MJ, and Baker NR. 1995. Does photorespiration protect the photosynthetic apparatus in french bean leaves from photoinhibition during drought stress? Planta 196:450-457. 10.1007/BF00203643

Buschmann C. 2007. Variability and application of the chlorophyll fluorescence emission ratio red/far-red of leaves. Photosynthesis research 92:261-271. 10.1007/s11120-007-9187-8

Butler W. 1978. Energy distribution in the photochemical apparatus of photosynthesis. Annual Review of plant physiology 29:457-478.

Campos H, Trejo C, Pena-Valdivia CB, Garcia-Nava R, Conde-Martinez FV, and Cruz-Ortega MR. 2014a. Stomatal and non-stomatal limitations of bell pepper (Capsicum annuum L.) plants under water stress and re-watering: Delayed restoration of photosynthesis during recovery. Environmental and Experimental Botany 98:56-64. 10.1016/j.envexpbot.2013.10.015

Campos H, Trejo C, Peña-Valdivia CB, García-Nava R, Conde-Martínez FV, and Cruz-Ortega MR. 2014b. Stomatal and non-stomatal limitations of bell pepper (Capsicum annuum L.) plants under water stress and re-watering: Delayed restoration of photosynthesis during recovery. Environmental and Experimental Botany 98:56-64. https://doi.org/10.1016/j.envexpbot.2013.10.015

Chaves MM, Pereira JS, Maroco J, Rodrigues ML, Ricardo CPP, Osorio ML, Carvalho I, Faria T, and Pinheiro C. 2002. How plants cope with water stress in the field. Photosynthesis and growth. Annals of botany 89 Spec No:907-916. 10.1093/aob/mcf105

Chen YJ, Yu JJ, and Huang BR. 2015. Effects of Elevated CO2 Concentration on Water Relations and Photosynthetic Responses to Drought Stress and Recovery during Rewatering in Tall Fescue. Journal of the American Society for Horticultural Science 140:19-26. 10.21273/jashs.140.1.19

Cornic G, and Fresneau C. 2002. Photosynthetic Carbon Reduction and Carbon Oxidation Cycles are the Main Electron Sinks for Photosystem II Activity During a Mild Drought. Annals of botany 89:887-894. 10.1093/aob/mcf064

Csintalan Z, Tuba Z, and Lichtenthaler HK. 1998. Changes in laser-induced chlorophyll fluorescence ratio F690/F735 in the poikilochlorophyllous desiccation tolerant plant Xerophyta scabrida during desiccation. Journal of Plant Physiology 152:540-544.

Peer] reviewing PDF | (2020:02:46083:3:0:NEW 20 Aug 2020) 
406

407

408

409

410

411

412

413

414

415

416

417

418

419

420

421

422

423

424

425

426

427

428

429

430

431

432

433

434

435

436

437

438

439

440

441

442

443

444

445

446

447

448

449

450

451

452

453

454

455

456
D'Ambrosio N, Szabo K, and Lichtenthaler HK. 1992. Increase of the chlorophyll fluorescence ratio F690/F735 during the autumnal chlorophyll breakdown. Radiation and environmental biophysics 31:51-62. 10.1007/bf01211512

Demmig-Adams B, and Adams WW. 2018. An integrative approach to photoinhibition and photoprotection of photosynthesis. Environmental and Experimental Botany 154:1-3. 10.1016/j.envexpbot.2018.05.006

Drake JE, Power SA, Duursma RA, Medlyn BE, Aspinwall MJ, Choat B, Creek D, Eamus D, Maier C, Pfautsch S, Smith RA, Tjoelker MG, and Tissue DT. 2017. Stomatal and nonstomatal limitations of photosynthesis for four tree species under drought: A comparison of model formulations. Agricultural and Forest Meteorology 247:454-466. https://doi.org/10.1016/j.agrformet.2017.08.026

Feller U. 2016. Drought stress and carbon assimilation in a warming climate: Reversible and irreversible impacts. Journal of Plant Physiology 203:84-94. https://doi.org/10.1016/j.jplph.2016.04.002

Flexas J, Barbour MM, Brendel O, Cabrera HM, Carriqui M, Diaz-Espejo A, Douthe C, Dreyer E, Ferrio JP, Gago J, Galle A, Galmes J, Kodama N, Medrano H, Niinemets U, PegueroPina JJ, Pou A, Ribas-Carbo M, Tomas M, Tosens T, and Warren CR. 2012. Mesophyll diffusion conductance to $\mathrm{CO} 2$ : An unappreciated central player in photosynthesis. Plant Science 193:70-84. 10.1016/j.plantsci.2012.05.009

Flexas J, Bota J, Loreto F, Cornic G, and Sharkey TD. 2004. Diffusive and metabolic limitations to photosynthesis under drought and salinity in $\mathrm{C}(3)$ plants. Plant biology (Stuttgart, Germany) 6:269-279. 10.1055/s-2004-820867

Flexas J, Carriqui M, Coopman RE, Gago J, Galmes J, Martorell S, Morales F, and Diaz-Espejo A. 2014. Stomatal and mesophyll conductances to CO2 in different plant groups: Underrated factors for predicting leaf photosynthesis responses to climate change? Plant Science 226:41-48. 10.1016/j.plantsci.2014.06.011

Flexas J, and Medrano H. 2002. Drought-inhibition of photosynthesis in C3 plants: stomatal and non-stomatal limitations revisited. Annals of botany 89:183-189. 10.1093/aob/mcf027

Fracheboud Y, and Leipner J. 2003. The Application of Chlorophyll Fluorescence to Study Light, Temperature, and Drought Stress. US: Springer

Gameiro C, Utkin AB, Cartaxana P, da Silva JM, and Matos AR. 2016. The use of laser induced chlorophyll fluorescence (LIF) as a fast and non-destructive method to investigate water deficit in Arabidopsis. Agricultural Water Management 164:127-136. 10.1016/j.agwat.2015.09.008

Gimeno TE, Saavedra N, Ogée J, Medlyn BE, and Wingate L. 2019. A novel optimization approach incorporating non-stomatal limitations predicts stomatal behaviour in species from six plant functional types. Journal of Experimental Botany 70:1639-1651. 10.1093/jxb/erz020

Gorry PA. 1990. General least-squares smoothing and differentiation by the convolution (Savitzky-Golay) method. Analytical Chemistry 62:570-573.

Gouveia-Neto AS, Silva Jr EA, Oliveira RA, Cunha PC, Costa EB, Câmara TJ, and Willadino LG. 2011. Water deficit and salt stress diagnosis through LED induced chlorophyll fluorescence analysis in Jatropha curcas L. oil plants for biodiesel. Imaging, Manipulation, and Analysis of Biomolecules, Cells, and Tissues IX: International Society for Optics and Photonics. p 79020A.

Grassi G, and Magnani F. 2005. Stomatal, mesophyll conductance and biochemical limitations to photosynthesis as affected by drought and leaf ontogeny in ash and oak trees. Plant, cell \& environment 28:834-849. 10.1111/j.1365-3040.2005.01333.x

Hajihashemi S, Brestic M, Kalaji HM, Skalicky M, and Noedoost F. 2020. Environmental pollution is reflected in the activity of the photosynthetic apparatus. Photosynthetica 58:529-539. 10.32615/ps.2019.179

PeerJ reviewing PDF | (2020:02:46083:3:0:NEW 20 Aug 2020) 
457

458

459

460

461

462

463

464

465

466

467

468

469

470

471

472

473

474

475

476

477

478

479

480

481

482

483

484

485

486

487

488

489

490

491

492

493

494

495

496

497

498

499

500

501

502

503

504

505

506

507

He L, Chen JM, Liu J, Zheng T, Wang R, Joiner J, Chou S, Chen B, Liu Y, Liu R, and Rogers C. 2019. Diverse photosynthetic capacity of global ecosystems mapped by satellite chlorophyll fluorescence measurements. Remote sensing of environment 232:111344. https://doi.org/10.1016/j.rse.2019.111344

Iqbal N, Hussain S, Raza MA, Yang C-Q, Safdar ME, Brestic M, Aziz A, Hayyat MS, Asghar MA, Wang XC, Zhang J, Yang W, and Liu J. 2019. Drought Tolerance of Soybean (Glycine max L. Merr.) by Improved Photosynthetic Characteristics and an Efficient Antioxidant Enzyme Activities Under a Split-Root System. Frontiers in Physiology 10. 10.3389/fphys.2019.00786

Kalmatskaya O, Karavaev V, and Gunar L. 2016. Fluorescent indices of oak and wheat leaves in dependence on chlorophyll content: SPIE.

Khatri K, and Rathore MS. 2019. Photosystem photochemistry, prompt and delayed fluorescence, photosynthetic responses and electron flow in tobacco under drought and salt stress. Photosynthetica 57:61-74. 10.32615/ps.2019.028

Krause G, and Weis E. 1991. Chlorophyll fluorescence and photosynthesis: the basics. Annual Review of Plant Biology 42:313-349.

Lamaoui M, Jemo M, Datla R, and Bekkaoui F. 2018. Heat and Drought Stresses in Crops and Approaches for Their Mitigation. Frontiers in chemistry 6. 10.3389/fchem.2018.00026

Lawlor DW, and Tezara W. 2009. Causes of decreased photosynthetic rate and metabolic capacity in water-deficient leaf cells: a critical evaluation of mechanisms and integration of processes. Annals of botany 103:561-579. 10.1093/aob/mcn244

Lee JE, Frankenberg C, van der Tol C, Berry JA, Guanter L, Boyce CK, Fisher JB, Morrow E, Worden JR, Asefi S, Badgley G, and Saatchi S. 2013. Forest productivity and water stress in Amazonia: observations from GOSAT chlorophyll fluorescence. Proceedings of the Royal Society B-Biological Sciences 280:9. 10.1098/rspb.2013.0171

Li QB, Huang WY, and Zhang GG. 2009. Chlorophyll Content Nondestructive Measurement Method Based on Vis/NIR Spectroscopy. Spectroscopy and Spectral Analysis 29:32753278.

Li QM, Liu BB, Wu Y, and Zou ZR. 2008. Interactive effects of drought stresses and elevated $\mathrm{CO} 2$ concentration on photochemistry efficiency of cucumber seedlings. Journal of Integrative Plant Biology 50:1307-1317. 10.1111/j.1744-7909.2008.00686.x

Li XY, Li Y, Chen AP, Gao MD, Slette IJ, and Piao SL. 2019. The impact of the 2009/2010 drought on vegetation growth and terrestrial carbon balance in Southwest China. Agricultural and Forest Meteorology 269:239-248. 10.1016/j.agrformet.2019.01.036

Lichtenthaler HK, and Rinderle U. 1988. The Role of Chlorophyll Fluorescence in The Detection of Stress Conditions in Plants. C R C Critical Reviews in Analytical Chemistry 19:S29S85.

Long SP, Humphries, S., \& Falkowski, P. G. 1994. Photoinhibition of photosynthesis in nature. Annual Review of Plant Biology 45(1):633-662.

Longenberger PS, Smith CW, Duke SE, and McMichael BL. 2009. Evaluation of chlorophyll fluorescence as a tool for the identification of drought tolerance in upland cotton. Euphytica 166:25-33. 10.1007/s10681-008-9820-4

Magney TS, Frankenberg C, Fisher JB, Sun Y, North GB, Davis TS, Kornfeld A, and Siebke K. 2017. Connecting active to passive fluorescence with photosynthesis: a method for evaluating remote sensing measurements of $\mathrm{Chl}$ fluorescence. New phytologist 215:1594-1608. 10.1111/nph.14662

Mathobo R, Marais D, and Steyn JM. 2017. The effect of drought stress on yield, leaf gaseous exchange and chlorophyll fluorescence of dry beans (Phaseolus vulgaris L.). Agricultural Water Management 180:118-125. 10.1016/j.agwat.2016.11.005

Maxwell K, and Johnson GN. 2000. Chlorophyll fluorescence--a practical guide. Journal of Experimental Botany 51:659-668. 10.1093/jexbot/51.345.659

Peer) reviewing PDF | (2020:02:46083:3:0:NEW 20 Aug 2020) 
508

509

510

511

512

513

514

515

516

517

518

519

520

521

522

523

524

525

526

527

528

529

530

531

532

533

534

535

536

537

538

539

540

541

542

543

544

545

546

547

548

549

550

551

552

553

554

555

556

557

558
Meng LL, Song JF, Wen J, Zhang J, and Wei JH. 2016. Effects of drought stress on fluorescence characteristics of photosystem II in leaves of Plectranthus scutellarioides. Photosynthetica 54:414-421. 10.1007/s11099-016-0191-0

Murchie EH, and Lawson T. 2013. Chlorophyll fluorescence analysis: a guide to good practice and understanding some new applications. Journal of Experimental Botany 64:39833998. 10.1093/jxb/ert208

Niinemets U, and Keenan T. 2014. Photosynthetic responses to stress in Mediterranean evergreens: Mechanisms and models. Environmental and Experimental Botany 103:2441. 10.1016/j.envexpbot.2013.11.008

Norikane J, Goto E, Kurata K, and Takakura T. 2003. A new relative referencing method for crop monitoring using chlorophyll fluorescence. Advances in space research : the official journal of the Committee on Space Research (COSPAR) 31:245-248. 10.1016/s02731177(02)00746-9

Nyachiro JM, Briggs KG, Hoddinott J, and Johnson-Flanagan AM. 2001. Chlorophyll Content, Chlorophyll Fluorescence and Water Deficit in Spring Wheat. Cereal Research Communications 29:135-142.

Pachauri RK, Allen MR, Barros VR, Broome J, Cramer W, Christ R, Church JA, Clarke L, Dahe Q, and Dasgupta P. 2014. Climate change 2014: synthesis report. Contribution of Working Groups I, II and III to the fifth assessment report of the Intergovernmental Panel on Climate Change: Ipcc.

Peña-Rojas K, Aranda X, and Fleck I. 2004. Stomatal limitation to CO2 assimilation and downregulation of photosynthesis in Quercus ilex resprouts in response to slowly imposed drought. Tree physiology 24:813-822. 10.1093/treephys/24.7.813 \%J Tree Physiology

Phillips OL, Aragao L, Lewis SL, Fisher JB, Lloyd J, Lopez-Gonzalez G, Malhi Y, Monteagudo A, Peacock J, Quesada CA, van der Heijden G, Almeida S, Amaral I, Arroyo L, Aymard G, Baker TR, Banki O, Blanc L, Bonal D, Brando P, Chave J, de Oliveira ACA, Cardozo ND, Czimczik Cl, Feldpausch TR, Freitas MA, Gloor E, Higuchi N, Jimenez E, Lloyd G, Meir P, Mendoza C, Morel A, Neill DA, Nepstad D, Patino S, Penuela MC, Prieto A, Ramirez F, Schwarz M, Silva J, Silveira M, Thomas AS, ter Steege H, Stropp J, Vasquez R, Zelazowski P, Davila EA, Andelman S, Andrade A, Chao KJ, Erwin T, Di Fiore A, Honorio E, Keeling H, Killeen TJ, Laurance WF, Cruz AP, Pitman NCA, Vargas PN, Ramirez-Angulo H, Rudas A, Salamao R, Silva N, Terborgh J, and Torres-Lezama A. 2009. Drought Sensitivity of the Amazon Rainforest. Science 323:1344-1347. 10.1126/science. 1164033

Pilon C, Snider JL, Sobolev V, Chastain DR, Sorensen RB, Meeks CD, Massa AN, Walk T, Singh B, and Earl HJ. 2018. Assessing stomatal and non-stomatal limitations to carbon assimilation under progressive drought in peanut (Arachis hypogaea L.). Journal of Plant Physiology 231:124-134. https://doi.org/10.1016/j.jplph.2018.09.007

Pilon C, Soratto RP, Broetto F, and Fernandes AM. 2014. Foliar or Soil Applications of Silicon Alleviate Water-Deficit Stress of Potato Plants. Agronomy Journal 106:2325-2334. 10.2134/agronj14.0176

Pinheiro C, and Chaves MM. 2011. Photosynthesis and drought: can we make metabolic connections from available data? Journal of Experimental Botany 62:869-882. 10.1093/jxb/erq340

Porcar-Castell A, Tyystjärvi E, Atherton J, van der Tol C, Flexas J, Pfündel EE, Moreno J, Frankenberg C, and Berry JA. 2014. Linking chlorophyll a fluorescence to photosynthesis for remote sensing applications: mechanisms and challenges. Journal of Experimental Botany 65:4065-4095. 10.1093/jxb/eru191

Rancourt GT, Ethier G, and Pepin S. 2015. Greater efficiency of water use in poplar clones having a delayed response of mesophyll conductance to drought. Tree physiology 35:172-184. 10.1093/treephys/tpv006

Peer) reviewing PDF | (2020:02:46083:3:0:NEW 20 Aug 2020) 
559

560

561

562

563

564

565

566

567

568

569

570

571

572

573

574

575

576

577

578

579

580

581

582

583

584

585

586

587

588

589

590

591

592

593

594

595

596

597

598

599

600

601

602

603

604

605

606

607

Rho H, Yu DJ, Kim SJ, and Lee HJ. 2012. Limitation Factors for Photosynthesis in 'Bluecrop' Highbush Blueberry (Vaccinium corymbosum) Leaves in Response to Moderate Water Stress. Journal of Plant Biology 55:450-457. 10.1007/s12374-012-0261-1

Salmon Y, Lintunen A, Dayet A, Chan T, Dewar R, Vesala T, and Hölttä T. 2020. Leaf carbon and water status control stomatal and nonstomatal limitations of photosynthesis in trees. New phytologist 226:690-703. 10.1111/nph.16436

Sharkey TD. 2016. What gas exchange data can tell us about photosynthesis. Plant Cell and Environment 39:1161-1163. 10.1111/pce.12641

Smith WK, Biederman JA, Scott RL, Moore DJP, He M, Kimball JS, Yan D, Hudson A, Barnes ML, MacBean N, Fox AM, and Litvak ME. 2018. Chlorophyll Fluorescence Better Captures Seasonal and Interannual Gross Primary Productivity Dynamics Across Dryland Ecosystems of Southwestern North America. Geophysical Research Letters 45:748-757. 10.1002/2017gl075922

Stirbet A, Lazar D, Kromdijk J, and Govindjee. 2018. Chlorophyll a fluorescence induction: Can just a one-second measurement be used to quantify abiotic stress responses? Photosynthetica 56:86-104. 10.1007/s11099-018-0770-3

Streit NM, Canterle LP, Canto MWd, and Hecktheuer LHH. 2005. As clorofilas Ciência Rural 35:748-755.

Su LY, Dai ZW, Li SH, and Xin HP. 2015. A novel system for evaluating drought-cold tolerance of grapevines using chlorophyll fluorescence. Bmc Plant Biology 15:12. 10.1186/s12870015-0459-8

Tezara W, Martinez D, Rengifo E, and Herrera A. 2003. Photosynthetic responses of the tropical spiny shrub Lycium nodosum (Solanaceae) to drought, soil salinity and saline spray. Annals of botany 92:757-765. 10.1093/aob/mcg199

Tribulato A, Toscano S, Di Lorenzo V, and Romano D. 2019. Effects of Water Stress on Gas Exchange, Water Relations and Leaf Structure in Two Ornamental Shrubs in the Mediterranean Area. Agronomy-Basel 9:19. 10.3390/agronomy9070381

Urban L, Aarrouf J, and Bidel LPR. 2017. Assessing the Effects of Water Deficit on Photosynthesis Using Parameters Derived from Measurements of Leaf Gas Exchange and of Chlorophyll a Fluorescence. Frontiers in Plant Science 8:18. 10.3389/fpls.2017.02068

Utkin AB, Felizardo R, Gameiro C, Matos AR, and Cartaxana P. 2014. Laser induced fluorescence technique for environmental applications. Second International Conference on Applications of Optics and Photonics: International Society for Optics and Photonics. p 928609.

Van Kooten O. 1990. The use of chlorophyll fluorescence nomenclature in plant stress physiology. Photosynthesis research 25.

Varone L, Ribas-Carbo M, Cardona C, Galle A, Medrano H, Gratani L, and Flexas J. 2012. Stomatal and non-stomatal limitations to photosynthesis in seedlings and saplings of Mediterranean species pre-conditioned and aged in nurseries: Different response to water stress. Environmental and Experimental Botany 75:235-247. 10.1016/j.envexpbot.2011.07.007

Wang WS, Wang C, Pan DY, Zhang YK, Luo B, and Ji JW. 2018. Effects of drought stress on photosynthesis and chlorophyll fluorescence images of soybean (Glycine max) seedlings. International Journal of Agricultural and Biological Engineering 11:196-201. 10.25165/j.jjabe.20181102.3390

Xu Q, Ma X, Lv T, Bai M, Wang Z, and Niu J. 2020. Effects of Water Stress on Fluorescence Parameters and Photosynthetic Characteristics of Drip Irrigation in Rice. Water 12. 10.3390/w12010289

PeerJ reviewing PDF | (2020:02:46083:3:0:NEW 20 Aug 2020) 
608 Yu Haiye YH, Zhang Lei. 2009. Relationship between laser-induced chlorophyll fluorescence

609

610 intensity and laser power. Transactions of the Chinese Society of Agricultural

611 Zhou L, Wang SQ, Chi YG, Li QK, Huang K, and Yu QZ. 2015. Responses of photosynthetic

612

$613 \quad 10.1038 /$ srep18254 parameters to drought in subtropical forest ecosystem of China. Scientific Reports 5:11.

614 Zhou SX, Medlyn B, Sabate S, Sperlich D, and Prentice IC. 2014. Short-term water stress

615

616

617 impacts on stomatal, mesophyll and biochemical limitations to photosynthesis differ consistently among tree species from contrasting climates. Tree physiology 34:1035-

618 1046. 10.1093/treephys/tpu072 
Figure 1

Schematic diagram of laser-induced chlorophyll fluorescence experimental system

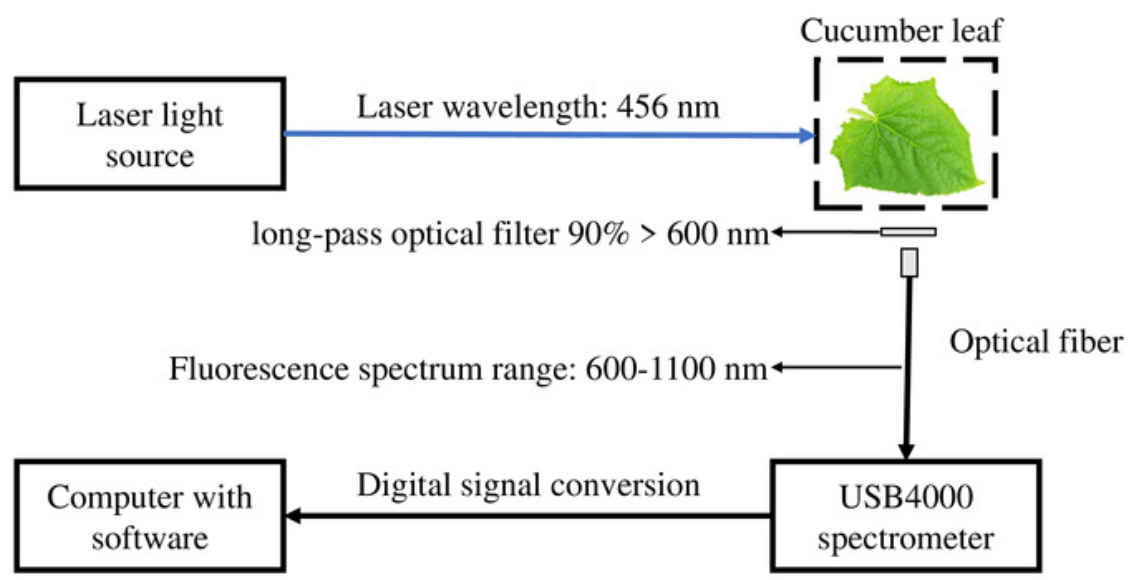




\section{Figure 2}

Variations of net $\mathrm{CO}_{2}$ assimilation rate and chlorophyll fluorescence parameters in control and drought stress

$(a, b) A_{n}$ ( net $\mathrm{CO}_{2}$ assimilation rate $\mu \mathrm{mol} \mathrm{m}^{-2} \mathrm{~s}^{-1}$ ), (c,d) $\mathrm{F}_{\mathrm{v}} / \mathrm{F}_{\mathrm{m}}$ (maximum quantum efficiency of PSII), (e,f) $L_{685} / L_{740}$ (Laser induced chlorophyll fluorescence intensity ratio). In the box plot, the points and short error bars represent the mean $( \pm S E)$ of $n=27$ per treatment, and the line and long error bars represent the median line and $95 \% \mathrm{Cl}$, respectively. In the line chart, the points and error bars reflect the mean $( \pm \mathrm{SE})$ of 3 replicate per treatment per date ( replicate 6 per treatment on the first day). The blue and red indicates the control and drought treatment, respectively. RMANOVA was used estimate the effect of treatment : * $\mathrm{P}<$ $0.05 ; * * \mathrm{P}<0.01 ; * * * \mathrm{P}<0.001 ;$ n.s. not significant. 

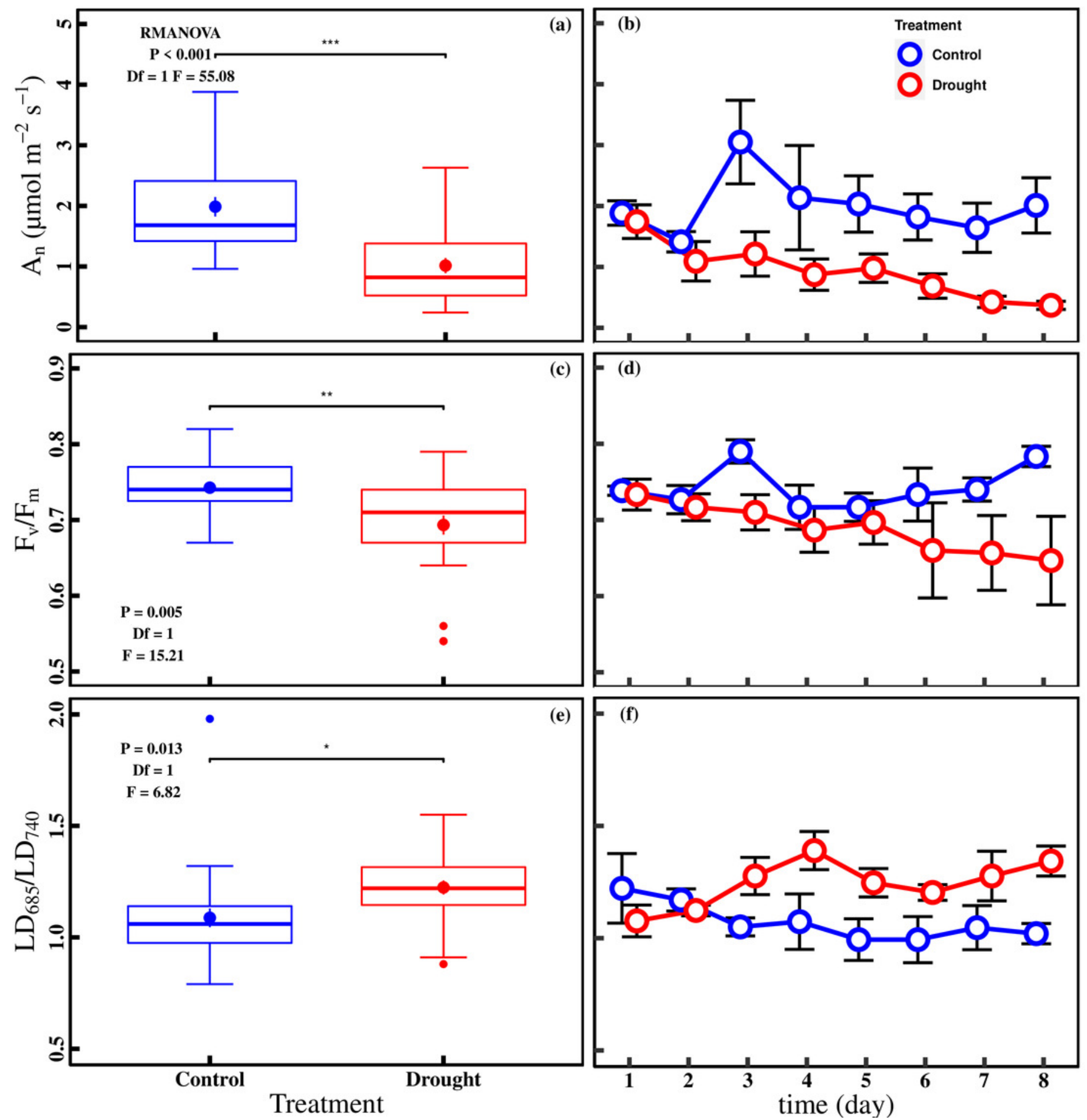


\section{Figure 3}

Variations of photosynthetic traits and total chlorophyll concentration in control and drought stress

$(a, b)$ Vcmax (Maximum carboxylation rate, $\mu \mathrm{mol} \mathrm{m}^{-2} \mathrm{~s}^{-1}$ ), (c,d) Jmax (Maximum photoelectron transfer rate, $\mu \mathrm{mol} \mathrm{m} \mathrm{m}^{-2}$ ), (e,f) gs (stomatal conductance, $\left.\mathrm{mol} \mathrm{m}^{-2} \mathrm{~s}^{-1}\right),(\mathrm{g}, \mathrm{h})$ Chlt (Total chlorophyll concentration, $\mathrm{mg} \mathrm{g}^{-1}$ ) in control and drought stress. In the box plot, the points and short error bars represent the mean $\left( \pm\right.$ SE) of $n=27$ per treatment $\left(n=15\right.$ of $\mathrm{Ch}_{t}$ per treatment), and the line and long error bars represent the median line and $95 \% \mathrm{Cl}$, respectively. In the line chart, the points and error bars reflect the mean $( \pm S E)$ of 3 replicate per treatment per date ( replicate 6 per treatment on the first day). The blue and red indicate the control and drought stress, respectively. RMANOVA was used estimate the effect of treatment : $* \mathrm{P}<0.05 ; * * \mathrm{P}<0.01 ; * * * \mathrm{P}<0.001 ;$ n.s. not significant. 

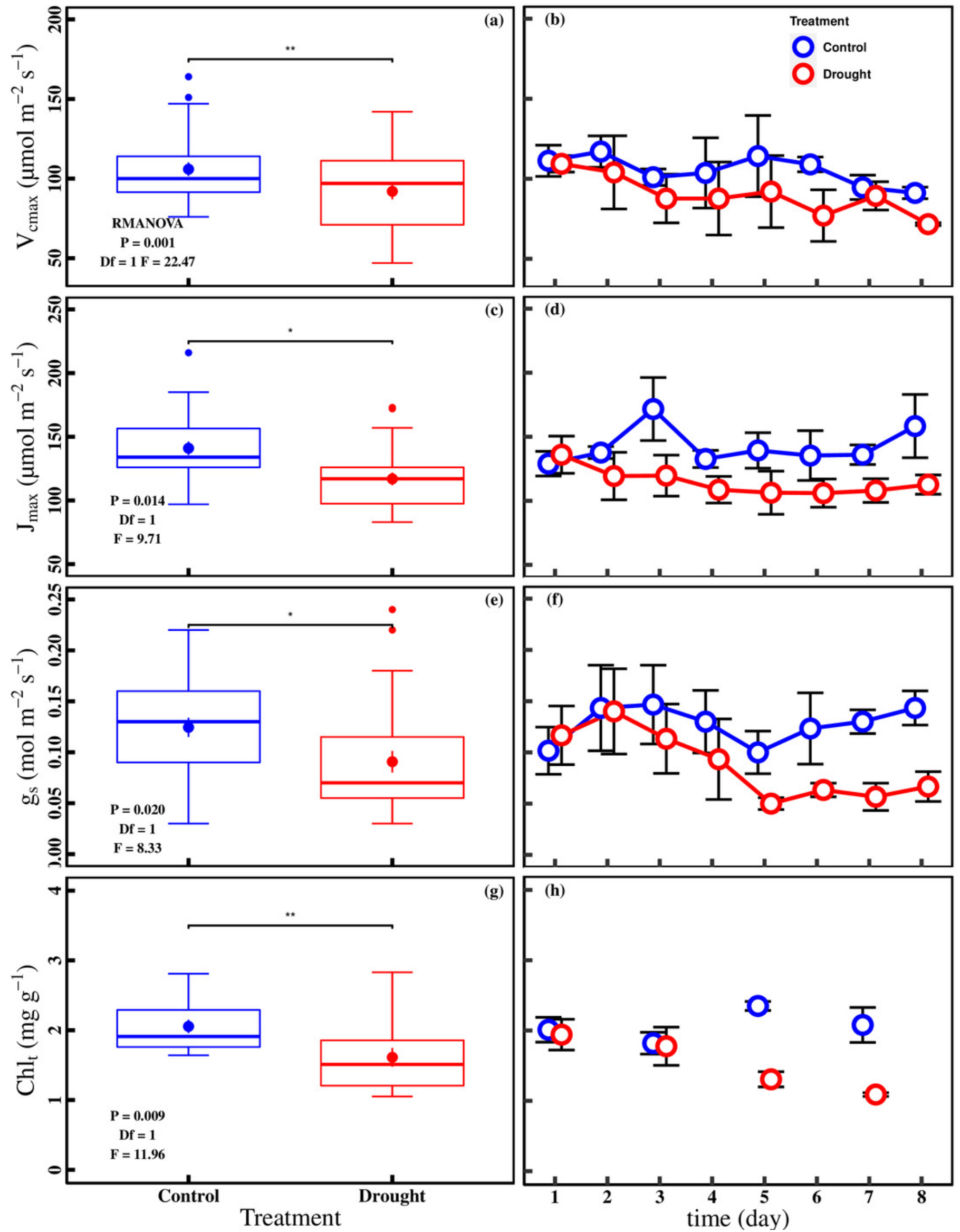

Peer) reviewing PDF | (2020:02:46083:3:0:NEW 20 Aug 2020) 


\section{Figure 4}

Relationships between chlorophyll fluorescence parameters and photosynthetic traits in the control and drought stress

(a) $A_{n}$ (net $\mathrm{CO}_{2}$ assimilation rate $\mu$ mol m $\mathrm{m}^{-2} \mathrm{~s}^{-1}$ ) and $\mathrm{V}_{\text {cmax }}$ (Maximum carboxylation rate, $\mu \mathrm{mol} \mathrm{m} \mathrm{m}^{-2}$ $s^{-1}$ ), (b) $A_{n}$ and $J_{\max }\left(\right.$ Maximum photoelectron transfer rate, $\mu \mathrm{mol} \mathrm{m}^{-2} \mathrm{~s}^{-1}$ ), (c) $A_{n}$ and $g_{s}$ (stomatal conductance, mol m $\mathrm{m}^{-2} \mathrm{~s}^{-1}$ ), (d) $\mathrm{A}_{\mathrm{n}}$ and $\mathrm{Chl}_{\mathrm{t}}$ (Total chlorophyll concentration, $\mathrm{mg} \mathrm{g}^{-1}$ ), (e) $\mathrm{F}_{\mathrm{v}} / \mathrm{F}_{\mathrm{m}}$ (maximum quantum efficiency of PSII) and $V_{\text {cmax }}$ (f) $F_{v} / F_{m}$ and $J_{\text {max }}(g) F_{v} / F_{m}$ and $g_{s},(h) F_{v} / F_{m}$ and $\mathrm{ChI}_{\mathrm{t}}$, (i) $\mathrm{LD}_{685} / \mathrm{LD}_{740}$ (Laser-induced chlorophyll fluorescence intensity ratio) and $\mathrm{V}_{\text {cmax }}$ (j) $F_{v} / F_{m}$ and $J_{\max }(k) F_{v} / F_{m}$ and $g_{s^{\prime}}(I) F_{v} / F_{m}$ and $C h l_{t}$. Linear fitting was used for correlation analysis ( $n=27$ for per treatment and $n=15$ of $\mathrm{Chl}_{t}$ for per treatment). The blue line and red line indicate the linear regression for the control and drought stress, respectively. 

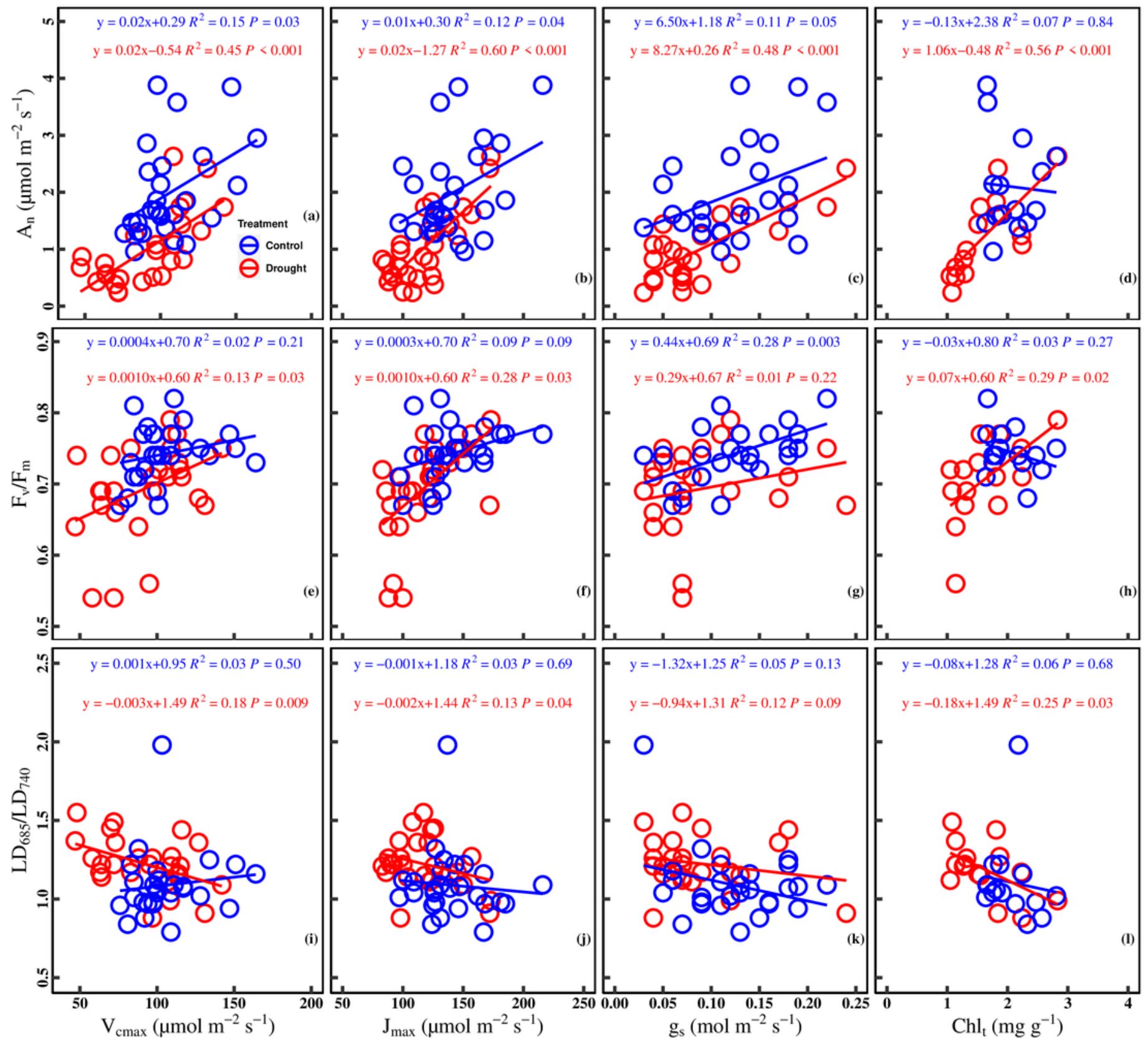
Figure 5

Relationships between net $\mathrm{CO}_{2}$ assimilation rate and chlorophyll fluorescence parameters in control and droght stress

(a) $A_{n}$ (net $\mathrm{CO}_{2}$ assimilation rate $\mu \mathrm{mol} \mathrm{m}^{-2} \mathrm{~s}^{-1}$ ) and $\mathrm{F}_{\mathrm{v}} / \mathrm{F}_{\mathrm{m}}$ (maximum quantum efficiency of PSII),

(b) or $A_{n}$ and $L D_{685} / L D_{740}$ (Laser-induced chlorophyll fluorescence intensity ratio). Linear fitting was used for correlation analysis ( $n=27$ for per treatment). The blue line and red line indicate the linear regression for the control and drought stress, respectively.

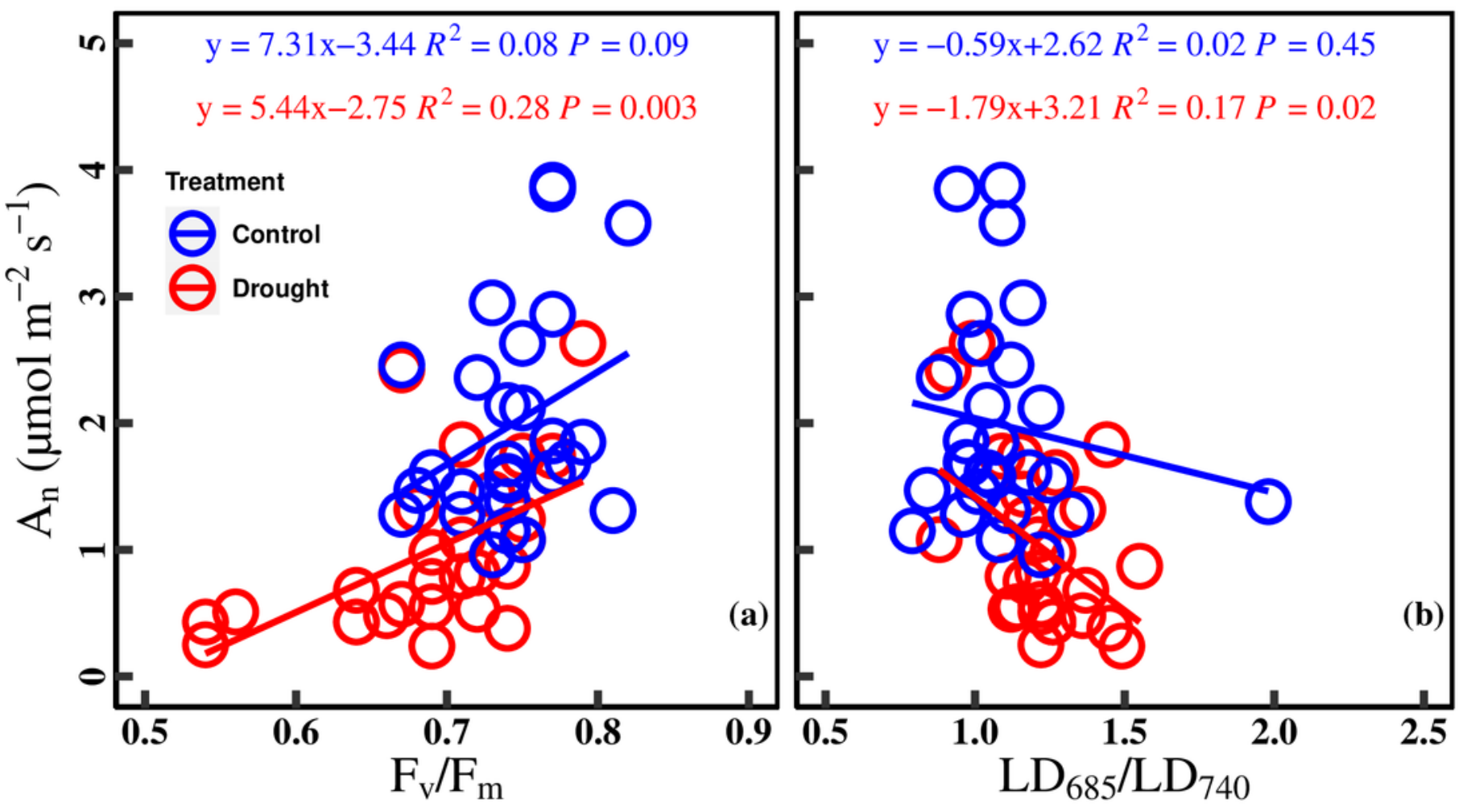

